\title{
DAS EXCELÊNCIAS DO PODER RÉGIO: DIMEN- SÕES PRECEPTIVAS NOS TEXTOS DE ANTÔNIO VIEIRA ${ }^{1}$
}

\author{
Marcos Antônio LOPES \\ Universidade Estadual de Londrina
}

\begin{abstract}
RESUMEN: En el campo de las ideas políticas el padre Antonio Vieira es una de las más curiosas figuras, tanto por por sus anacronismos y su peculiar concepción de la realidad histórica y de la Historia como ciencia, como por fundamentar sus textos de forma casi exclusiva en las Sagradas Escrituras. Consejero del Rey, confesor de la Reina y preceptor del Infante de Portugal, la obra de Vieira está repleta de consejos para príncipes. Este artículo aborda determinadas dimensiones preceptivas de algunos de sus textos históricos y políticos selecionados entre los Sermones y las Obras Varias.
\end{abstract}

PALABRAS CLAVE: Intelectuales y poder político; espejo de príncipes; Antonio Vieira.

ABSTRACT: In the field of History of Ideas, Vieira is one of the most curious figures due to his anachronisms and his idiosyncratic concepts of the effective history and the History-knowledge as well as for explaining his texts rather exclusively based on the Holy Scripture. As the King's adviser, the Queen's confessor and preceptor of the infant of Portugal, Vieira's work is full of advice to the princes. This article deals with certain instructive dimensions of some of his historical and political texts selected among the Sermons and his other works.

KEYWORDS: Intellectuals and the Political Power; Models of Princes; Antonio Vieira.

O propósito desta abordagem é distinguir, no conjunto de textos selecionados, os ardis, os engenhos, as maquinações, enfim, as "astúcias" que Vieira urdiu para a apresentação de um elenco de personagens exemplares e heróicos — bem como um cortejo de contra-modelos - , textos nos quais sempre sabe distinguir o bem do mal e a decisão mais acertada a tomar. Dos exemplos das coisas passadas que narra a sua História Sagrada resultam os êxitos a imitar, e os equívocos a evitar, em meio a um emaranhado de normas úteis, verdadeiro conteúdo programático para os grandes homens de seu tempo, sobretudo os príncipes. Polígrafo de extensa lavra, Antônio Vieira produziu uma obra que se estende por um período de mais de setenta anos de intensa atividade intelectual. No conjunto de sua produção há

\footnotetext{
${ }^{1}$ Recibido el 20 de junio de 2011. Aceptado en el Consejo de 8 de noviembre de 2011.
} 
numerosos textos nos quais o autor desenvolve largas reflexões sobre a realeza sagrada na história do mundo, incluindo a Cristandade. ${ }^{2}$

E será na dimensão preceptiva de suas considerações sobre o príncipe que se pretende situar a discussão. Os textos selecionados são alguns dos denominados "históricos e políticos" ou outros designados pelo rótulo um pouco mais flexível de "obras várias" - havendo coincidência de títulos segundo os critérios dos editores e das edições —, mas sempre com destaque para os que foram direcionados aos príncipes, em diferentes conjunturas da vida do autor. Dessa forma, o interesse maior será pelas matérias que dizem respeito ao Portugal metropolitano, mais do que ao Portugal ultramarino, sabendo-se que Vieira produziu muito acerca do primeiro, quando se encontrava em regiões do segundo. De qualquer forma, o aspecto central em foco será o das imagens régias, e estas aparecem indistintamente na produção literária do autor, estivesse ele no Brasil, em Portugal, na França, na Holanda ou na Itália.

Assim sendo, é certo que numa interpretação que se pretende abordagem contextualista de obras de pensamento será preciso atentar para um problema teórico que amplia o grau de complexidade da análise política dos textos de Vieira, dos sermões em particular. Esses são textos que possuem mais de um "lugar de elaboração", já que concebidos em uma certa altura da vida do autor, e reelaborados em outra. Exemplo: alguns foram urdidos no serviço de el-rei e proferidos em sua presença, para serem retomados décadas mais tarde na solidão do claustro, na Bahia. Há também sermões elaborados nos anos 1630, outros na década de 90 do século XVII. Além dos mais de 60 anos que separam algumas obras de outras, há ainda as diferentes audiências às quais foram dirigidas. Isso altera bastante os aspectos implicados como, por exemplo, as questões de intencionalidade autoral, elemento de base para a análise de ações políticas propostas por um personagem histórico marcado por circunstâncias específicas. ${ }^{3}$ Tanto assim que, o sermão que lemos hoje é muito mais obra de escritor do que de orador, sugerem alguns de seus intérpretes.

\footnotetext{
${ }^{2}$ Explorações anteriores de nossa própria autoria acerca de tais questões podem ser encontradas nas seguintes referências: LOPES, M.A. (2010), «Antônio Vieira: uma leitura simbólica da história universal». Revista do Centro de Estudos Portugueses (UFMG). v.30, pp.159-183; LOPES, M.A. (2008) «Ardis, engenhos, maquinações: astúcias do padre Vieira», Revista do Centro de Estudos Portugueses (UFMG). v.28, pp. 37-51; e LOPES, M.A. (2008), Antiguidades Modernas: História e Política em Antônio Vieira. São Paulo: Edições Loyola.

3 Algumas alternativas teóricas para a interpretação da parenética vieiriana são consideradas por PÉCORA, Alcir (1994). Teatro do Sacramento: a unidade teológico-retórico-política dos sermões de Antônio Vieira. São Paulo: Edusp, pp. 43ss.
} 
Mais realista que o próprio D. João IV - tornou-se conselheiro do rei, confessor da rainha Dona Luísa e preceptor do infante D. Teodósio - , Vieira enfrentou os inquisidores e os colonos escravizadores de índios no Brasil, além de terçar armas com adversários numerosos e influentes na corte brigantina nos anos heróicos da Restauração. Vieira foi um quase ministro da propaganda régia - um "embaixador sem pasta", no dizer de Alcir Pécora -, que não mediu esforços para colocar as suas alegorias políticas em prol do soberano. Para louvar as virtudes do rei deixava até mesmo Deus em condição meio apagada.

A sua concepção da realeza sagrada como centro gerador da estabilidade política se formou não apenas à luz de uma cultura meramente livresca, mas frente a problemas históricos reais: a freqüente ameaça de Castela, a perda progressiva das possessões ultramarinas portuguesas, a instabilidade interna gerada por uma elite oportunista, dentre outros fatores. As suas reflexões políticas tão abundantemente espalhadas em praticamente todos os seus textos podem ser encaradas, então, como uma resposta engajada a situações impostas por um tempo de incertezas. Combatendo ou criticando as mazelas de sua época, como a corrupção dos administradores coloniais e as ações persecutórias da Inquisição portuguesa - energia esterilizante da prosperidade do reino - Vieira alertava que o primaz da política deveria ter interesse em proteger da força irracional todos os particulares, com vistas à prosperidade geral.

Nos textos históricos e políticos de Vieira, o rei está sempre alerta para a preservação de uma ordem terrena desejada por Deus, e por Ele confiada aos príncipes. Vieira acreditava que as ações dos homens eram fiscalizadas por uma Providência Divina, de tal modo que, por inexplicáveis e surpreendentes que pudessem parecer alguns eventos particulares, eles se sucediam em uma seqüência regulada. Um príncipe virtuoso não precisa temer as dificuldades do caminho pois, seguindo na senda da bondade e da fé, será sempre amparado. Mas, em caso de desvios dos príncipes, o providencialismo de Vieira assume um conteúdo ameaçador. Para livrar a sociedade política da corrupção, Deus se vinga, por meio da humilhação e queda dos reis ímpios e perversos. A tradição bíblica e a própria história profana estão repletas desses exemplos, que ele cita com riqueza de detalhes.

E o autor vai ressaltando os fatos históricos que lhe parecem mais ilustrativos. Na história de Portugal, por exemplo, saca o episódio da paralisia do rei. Ao pôr sua mãe a ferros, por causa de uma disputa política, Afonso Henriques teria sido privado dos movimentos das pernas, perdendo assim a sua condição de cavaleiro. Vieira deu crédito a essa estranha explicação, o que, aliás, está em sintonia com a sua concepção providencialista da história. Ao longo do século XVII, era comum a 
convicção em intervenções providenciais de um Deus particularmente empenhado nos rumos das nações e dos indivíduos. E mais ainda em Portugal, terra do segundo povo eleito, colaborador direto na redenção do mundo, segundo as concepções políticas de Vieira, e de muitos de seus contemporâneos.

Para Vieira, a soberania do príncipe cristão é incontestável porque ele é a representação simbólica da paternidade divina. Um bom exemplo histórico que o autor oferece para ancorar a sua teoria numa origem sagrada da realeza encontra-se na História do Futuro, ao ressaltar a comunicação de Cristo com o fundador do reino, Afonso Henriques: "Vencerás Afonso, e não serás vencido". A aparição miraculosa do Cristo crucificado inspirando o fundador da monarquia portuguesa a enfrentar o numeroso e aparentemente imbatível exército de infiéis aparece descrita em documentos bem posteriores aos sucessos do jovem príncipe, intervenção providencial que Vieira reproduz com a sua peculiar credulidade. As Actas das Cortes de Lamego e a Chronica de Cister, por exemplo, não são contemporâneas do objeto histórico que descrevem. De fato, foi no século XV que surgiu a lenda da aparição de Cristo a Afonso Henriques, na véspera da batalha de Ourique. Porém, foi no século XVII, durante o domínio espanhol, que a lenda se propagou.

Assim sendo, o príncipe cristão de Vieira não é pura e simplesmente um agente político terreno. Ele é o instrumento eficaz da construção dos laços identitários de uma comunidade de destino peregrinando na terra rumo a uma época gloriosa. As virtudes religiosas devem ser cultivadas pelo príncipe cristão, para atuarem como freio moral contra o desencadeamento das paixões. Nos príncipes, elas devem aproximar-se das "perfeições" dos grandes personagens bíblicos. No "Sermão de ação de graças pelo nascimento do príncipe D. João" há uma extensa galeria dos soberanos portugueses de Borgonha e de Avis, com as suas respectivas virtudes exaltadas pelo padre cortesão. Exceção feita ao cardeal-rei D. Henrique, o tio de D. Sebastião, talvez pela natureza efêmera de seu reinado. À moda de Plutarco, ídolo de dez entre dez escritores daquele tempo, os textos de Vieira estão carregados de ações exemplares de varões de alta linhagem. Há seqüências de empolgados "elogios aos reis de Portugal", para recordar o título do livro do alcobacense Frei Bernardo de Brito. Com efeito, as imagens régias formam um bloco temático que atravessa toda a produção de Vieira.

O espaço do rei nos sermões é identificado por Alcir Pécora nos seguintes termos: "E há, de fato, nos sermões vieirianos um papel privilegiadíssimo atribuído

\footnotetext{
${ }^{4}$ VIEIRA, António (2005), História do Futuro. Brasília: Editora da UnB, pp. 171. (Organização: Aleixo, José C.B.).
} 
ao rei - o que obviamente não surpreende (...)".5 As razões conjunturais apresentadas por Pécora são várias e relevantes para a contextualização do personagem em suas funções de conselheiro político. Por ora cabe acentuar que a personalidade do príncipe é central na "máquina do governo". E não que essa "máquina" não seja também concebida como um aparelho jurídico e administrativo que necessita mostrar-se em adequação diante das necessidades dos novos tempos. O que há de importante é que as virtudes cristãs do príncipe qualificam os projetos do Estado, acreditava Vieira.

Em sua dimensão de conselheiro do príncipe, Vieira se mostra mais próximo da linhagem moralista neo-escolástica do que se distingue como escritor alinhado com os modernos analistas políticos emergentes na Europa desde o Renascimento. Homem da Companhia de Jesus, profundamente implicado com as discussões neotomistas, não poderia ter sido muito diferente. Assim é que o príncipe cristão é o seu grande herói constituindo-se, a monarquia, na forma de governo de sua predileção, sem nenhuma concorrência.

Sem dúvida, as dimensões preceptivas nos textos históricos e políticos de Vieira demonstram uma concepção complexa das funções régias por parte do autor. No "Sermão histórico e panegírico, nos anos da Sereníssima Rainha Nossa Senhora" - texto produzido em momento menos afortunado de sua vida, porque já bem afastado do núcleo das decisões do poder - aparece o desfile das excelsas qualidades de D. João IV, num retrato que Vieira concebeu para servir como o espelho de seu filho, el-rei D. Pedro. ${ }^{6}$ Para Vieira, o seu modelo de príncipe é tão grande e valoroso que a ele Deus reservou o império do mundo. Conselheiro por vezes audacioso dos poderosos, aos quais designa um pouco iradamente no "Sermão do Bom Ladrão" por "sujeitos da suprema esfera", Vieira quis moldar a consciência moral dos príncipes de seu tempo, por meio de exemplos extraídos do Velho Testamento. Como conselheiro de príncipes Vieira parece revelar-se um cortesão muito empenhado, insistente e até ameaçador em seu ofício. São dessa natureza as suas admoestações ao rei D. Pedro II:

"Perdeu-se lastimosamente el-rei Roboão, e do reino inteiro das doze tribos, que tinha herdado, apenas deixou duas a seus descendentes. Mas por

${ }^{5}$ PÉCORA, Alcir. Teatro do Sacramento. Op. cit., p. 102.

${ }^{6}$ Cf. VIEIRA, António (1957), «Sermão histórico e panegírico, nos anos da Sereníssima Rainha Nossa Senhora». In: —. Sermões. São Paulo: Editora das Américas. Volume XXII. p. 179. Acerca desse aspecto veja também a História do Futuro. Op. cit., p. 223s. 
quê? Só porque não quis seguir os conselhos e conselheiros de seu pai ...".7

O diretor de consciência deseja tomar o lugar que lhe parece ser próprio na direção da nau do Estado, ainda que não o queiram por perto, como em realidade aconteceu nos reinados de Afonso VI e Pedro II.

Na História do Futuro, a realeza sagrada concebida por Vieira atua como o instrumento por excelência das intervenções de Deus entre os homens. A influência da Providência Divina é um elemento dominante em sua narrativa, e a história humana é vista como uma espécie de épico religioso em que se sucedem os impérios do Oriente em direção ao Ocidente. Em seu livro Vieira concebeu o príncipe como um agente envolvido por uma auréola de sacralidade e de mistério. A soberania verticalizada do monarca, que está em comunhão com a vontade mantenedora do mundo, faz da realeza um instrumento eficaz da intervenção divina. Isso ocorre para que a Providência possa orientar a sociedade política, sempre no sentido da realização do bem público.

A crença universalmente espalhada desde a mais remota Antigüidade de que a realeza era detentora legítima do poder de coerção — mas que também podia dominar forças sobrenaturais para exercer com maior grau de eficácia a hegemonia sobre uma dada comunidade política — , manteve-se viva no mundo cristão, e com tanto mais força nos países católicos, nos séculos da Idade Média e da Época Moderna. Depois das culminâncias a que havia chegado na Idade Média, no século XVII, a literatura política celebrativa de uma concepção cristã de realeza alcançou alguns momentos de glória com a obra de um Bossuet e de um Vieira. Muitos tratados de filosofia moral e política, além do antigo gênero Orações Fúnebres, ressurgiram impulsionados pelas novas exigências da propaganda monárquica, nos tempos de afirmação do absolutismo na Europa.

Na História do Futuro, Vieira tenciona desvendar ao príncipe cristão os mistérios sagrados que envolvem a autoridade régia. Seu interesse é ensinar aos monarcas que, mesmo sendo escolhidos pelos desígnios mais secretos, e nascidos com atributos sobre-humanos que os colocam acima da condição dos mortais comuns, os reis não devem se desviar um só instante do caminho do bem. Constituindo-se no vínculo sacramental da sociedade - o núcleo sagrado que estabelece a unidade do corpo político — , eles devem cultivar ao máximo grau todas as altas qualidades morais de um complexo catálogo de virtudes régias:

\footnotetext{
7 VIEIRA, António. «Sermão histórico e panegírico, nos anos da Sereníssima Rainha Nossa Senhora». Op. cit., p. 180.
} 
"para com Deus - a religião, a piedade, o zelo —; para consigo - a temperança, a modéstia, a sobriedade —; para com os súditos — a prudência, a justiça, a clemência —; para com os estranhos — a vigilância, a fortaleza, a verdade". 8

E mais um extenso rosário de predicados. Mas é certo que Vieira vai bem mais longe em suas ideias sobre o príncipe cristão:

"O filho do homem é Cristo; o quase filho do homem é o quase Cristo, ou vice-Cristo. Em suma, que assim como Cristo, enquanto supremo Senhor no espiritual, fez um vice-Cristo com o poder universal da Igreja, que é o Sumo Pontífice, assim enquanto supremo Senhor no temporal, há de fazer outro vice-Cristo com o poder universal do mundo, que é o imperador, de que falamos". 9

As implicações de uma suposta concepção de realeza cristocêntrica presente nos textos de Vieira remetem a uma noção medieval de poder político secular: a de que o rei seria o mediador de Cristo entre Deus e os homens. Essa noção não frutificou por muito tempo na Baixa Idade Média, seguindo seu caminho histórico como apanágio das legitimações do poder papal. Como afirma Ernst Kantorowicz, a doutrina papal finalmente negou a natureza clerical do rei. Portanto, teve de ser substituída por outras formas de justificação do poder régio, mas que não deixaram de abastecê-lo de dimensões sacras, segundo as convenções e as necessidades da época. Ao que parece, Vieira continuou lidando com uma concepção que não mais vigorava na esfera das justificativas teológico-políticas do poder régio, ao menos desde os séculos XII e XIII.

Mas o que importa notar é que o jesuíta vai buscar nas Escrituras grandes exemplos de vida entre os reis e os profetas. Há alguns indícios de que a sua visada política conserva elementos residuais dos espelhos de príncipes da Idade Média. No plano do método de ensino das virtudes, Vieira ainda procede como os escritores desse velho gênero didático-político. Ao que parece, algumas de suas ideias exprimem tradições muito antigas, esquemas e fórmulas que se arrastavam desde muitos séculos. Mas não são ideias puras ou conceitos abstratos a matéria preceptiva de Vieira. Se assim fossem ensinadas, as virtudes dificilmente se

${ }^{8}$ VIEIRA, António. «Sermão histórico e panegírico, nos anos da Sereníssima Rainha Nossa Senhora». Op. cit., p. 179s.

${ }^{9}$ VIEIRA, António. «Sermão de ação de graças pelo nascimento do príncipe D. João». «Sermão de ação de graças pelo nascimento do príncipe D. João, primogênito de SS. Magestades, que Deus guarde (1688)». In: —. Obras completas do padre Antonio Vieira. Porto: Lello \& Irmão, 1951. Volume XV. p. 26. 
tornariam cabedal dos príncipes. Pelo contrário, o conhecimento e a interiorização das virtudes se realizam a partir dos exemplos de modelos históricos ou lendários - como procedia até mesmo um historiador como Maquiavel ao citar Rômulo e Teseu - , ou pela combinação da lenda e da história real de personagens virtuosos.

Na História do Futuro, e em vários outros de seus textos históricos e políticos, parecem ser abundantes as homenagens obrigadas e o relevo das "virtudes imortais" do príncipe reinante em seu tempo. D. João IV é o personagem mais recorrente nas suas obras, normalmente na condição do príncipe que vai ressuscitar para exercer o império sobre o universo. Portugal é lembrado por Vieira como o triunfo de toda a Cristandade, reino para o qual foram reservadas as maiores glórias:

"Não era por certo menos Golias o Oceano armado de tempestades e horrores, nem menor gigante o Oriente estendido em tantos e poderosos impérios, e, contudo, para domar a braveza de um, e conquistar a potência do outro, nem Deus escolheu entre os reinos outro reino que o de Portugal, nem entre as nações outra nação que os portugueses". 10

Vieira foi leitor atento de diversas tradições intelectuais. Ele se comunicava com uma legião de autores antigos e modernos. Aliás, a sua obra está repleta de paralelos daquilo que se denominou, na tradição literária européia, até os meados do século XVIII, a Querela dos Antigos e Modernos. Tomando em consideração as intenções preceptivas de Vieira, a História do Futuro é também fonte vasta para uma problemática acerca desse tema, notadamente no que diz respeito aos regimes políticos da Antigüidade e do próprio tempo do autor. Um exemplo: as virtudes do Ciro persa são as mesmas a serem cultivadas pelo "Ciro espanhol": "Oh, que caso tão parecido ao nosso! Oh, que ação tão digna de se santificar e fazer cristã, passando de um rei gentio a um rei católico!". ${ }^{11}$

$\mathrm{O}$ argumento de Vieira: reconheça o rei da Espanha a liberdade de Portugal e Deus lhe concederá outros favores. Isso para dizer que, quase sempre, cabe a imitação dos Antigos como norma de comportamento político. Ciro é figura modelar para os príncipes da Cristandade - mesmo carregando a "desvantagem" histórica de não ter sido rei católico —, porque ele seguiu os decretos de Deus. Vieira aborda o seu exemplo como o "mais claro espírito de nosso tempo". E segue o autor à página 205 desta mesma edição da História do Futuro: "Não sei que

\footnotetext{
${ }^{10}$ VIEIRA, António. «Sermão de ação de graças pelo nascimento do príncipe D. João». Op. cit., p. 62

${ }^{11}$ VIEIRA, António. História do Futuro. Op. cit., p. 197ss.
} 
possa haver mais claro espelho do nosso caso. Se Espanha se quiser ver e compor a ele, leia as profecias que neste livro vão escritas e já cumpridas". Essa análise de Vieira situa-se no tempo das lutas da Restauração e os freqüentes paralelos com a Espanha tornam-se compreensíveis.

Então, fica-se sabendo uma vez mais que os exemplos bíblicos são os melhores preceitos dos príncipes modernos. Aliás, a questão dos Antigos e Modernos é recorrente não apenas na História do Futuro. Vieira deu tal importância a esse assunto que é um desafio relevante extrair aspectos mais definidos de suas concepções acerca das vidas paralelas dos príncipes das diferentes eras. As histórias são compostas por ações que os ocupam, e tudo nelas parece ser feito preferencialmente para seu uso. Se a experiência é necessária aos príncipes para adquirir aquela prudência que os leva a reinar bem, não há nada mais útil para a sua instrução do que acrescentar aos exemplos dos séculos passados as experiências por eles adquiridas todos os dias:

"E se alguém com razão perguntar de que princípios se pode inferir politicamente que este império universal, e último, se haja de levantar nos últimos fins ou raias do Ocidente, respondo que da experiência havida pelas histórias, que são aquele espelho inculcado por Salomão, em que, olhando para o passado, se antevêem os futuros". 12

Nos textos históricos e políticos, o discurso de Vieira se volta conscientemente para o enaltecimento e para a afirmação da autoridade régia. $O$ apelo aos personagens da tradição sagrada e os constantes paralelos históricos de reis Antigos e Modernos, para além das lições morais ao príncipe reinante, tencionam enraizar o poder régio na autoridade incontestável da tradição bíblica. $\mathrm{O}$ discurso político de Vieira está impregnado de uma retórica tradicional e de símbolos que, presentes já nos textos dos séculos XV e XVI, alimentaram a literatura política e, sobretudo, o pensamento monarquista ibérico durante o século XVII.

Seus textos históricos e políticos são dissertações de aparato retórico elevado, e muito engajadas em construir, com eloqüência fosforescente, uma ordem política ideal. O método de análise histórica e política adotado por Vieira tinha como uma de suas intenções centrais garantir à soberania do príncipe cristão um reconhecimento completo, incontestável, num tempo em que as metáforas religiosas ainda possuíam o efeito de verdades eternas. Sua defesa do direito divino dos reis — direito válido tanto para os hebreus antigos quanto para o Portugal dos

\footnotetext{
${ }^{12}$ VIEIRA, António. «Sermão de ação de graças pelo nascimento do príncipe D. João». Op. cit., p. 84.
} 
Bragança -, situa a realeza cristã para muito além da história e da política profanas.

Vieira alegava que o príncipe cristão deveria perseguir, em suas ações políticas, finalidades espirituais inspiradas pela Providência. As Sagradas Escrituras seriam o seu farol, o guia seguro para recomendar as ações necessárias ao monarca virtuoso. Colocando a figura do príncipe de direito divino no topo de seu sistema hierárquico, o autor reduz quase todo o espaço da crítica a este personagem. Aos príncipes cabe se submeterem a ensinamentos válidos para todos os tempos. Eles não podem se desviar das tradições e dos costumes do reino, no que são igualmente tutelados por uma vontade transcendente. A Providência envolve a ordem política, interferindo no mundo, com freqüência, para ditar as leis ou para corrigir com pragas e castigos as distorções provocadas por maus príncipes. A ordem do mundo está nas mãos do Criador, sempre pronto a intervir sobre as ações do soberano. Há que se considerar, ainda, a particular justiça que se fará aos reis, no dia do juízo final, reflete Vieira em discurso proferido na Capela Real no ano de 1650:

"Mas, (...) chegarão finalmente os anjos ao lugar dos reis. Não se verão ali sitiais nem outros aparatos e majestade, mas todos sós, e acompanhados somente de suas obras, estarão em pé como réus. Conhecer-se-ão distintamente quais foram os reis de cada reino, quais os de Hungria, quais os de França, quais os de Inglaterra, quais os de Castela, quais os de Portugal. E desta maneira irão os anjos tirando de cada coroa aqueles que foram maus reis". 13

Para Vieira, há uma clara articulação e uma unidade entre a sociedade política e o mundo sobrenatural. Na História do Futuro, o simbolismo celeste que envolve a realeza hebraica é o ponto fundamental da argumentação do autor. Israel surge como uma monarquia que pode ser comparada ao céu. Há uma dimensão cósmica na realeza antiga, que atua como elo de uma fusão vertical entre dois reinos. $\mathrm{O}$ mundo transcendente se irradia na terra por mediação de um pólo dotado de uma centelha sagrada. Segundo Vieira, ao príncipe cristão cabe uma espécie de coregência do mundo. Somente a dignidade, a força e a autoridade da realeza podem sustentar uma ordem pública que, sem a presença desse agente, tende à desagregação. Exemplo recorrente: D. João IV. Essa interposição do príncipe entre dois mundos assegura a ordenação da cidade dos homens, para colocá-la em conformidade com o equilíbrio celeste.

13 VieIRA, António. «Sermão da Primeira Dominga do Advento». In: PÉCORA, Alcir. (Org.). Escritos Históricos e Políticos. Op. cit. p. 75. 
$\mathrm{Na}$ ausência do príncipe perfeito entre os vivos, Vieira chega à solução fantástica da sua ressurreição, para o advento do Quinto Império. Para ele, as ressurreições não são apenas possíveis, mas até muito freqüentes. Elas ocorrem na história para consumar os desígnios da Providência. Ora, Deus pode derrogar a lei da morte, como fez com Lázaro. E o ator que vai transformar a realidade não será necessariamente um personagem fixo. É que Vieira vai alternando as figuras - por ressurreição ou simples transferência —, à medida em que a realidade contraria os seus prognósticos. Aliás, a realidade é particularmente persistente em desconfirmar as previsões do escritor. Mas Vieira sempre contrapõe golpes de imaginação inspirados nas Escrituras. Nos textos bíblicos encontra saídas criativas para explicar todas as profecias não confirmadas, e assim vai adiando as promessas já que, na história dos homens, é muito difícil perceber uma conclusão.

Essas agudezas, essas astúcias, esses golpes de espírito confirmam a sua fé no grande futuro do reino. A sua capacidade de imaginação permiti-lhe explicar a orgulhosos leitores de outras terras - mormente os de reinos maiores e mais poderosos como Espanha, França, Inglaterra - a pertinência de uma, por assim dizer, Cristandade Universal, liderada por um país tão pequeno como Portugal. A resposta estava na própria história deste reino: nasceu de uma aliança com Cristo, e desvendou todos os mundos até então desconhecidos. Portanto, Portugal está justificado como a cabeça da Cristandade, porque o reino eleito encarregado da maior missão histórica de um povo sobre a terra: a realização do Quinto Império. Acerca dos anseios populares em torno dessa monarquia universal, a esperança de sua realização era pregada nos púlpitos, nas sabatinas escolares. A dita esperança se propagava entre as elites e a plebe, entre os homens de letras e os mais ignorantes. Ela era atiçada nas Universidades, dominadas pelas Ordens religiosas. Mas em Évora, reduto dos jesuítas, fazia uma autoridade ainda maior.

Como autor barroco, as concepções do autor estão cheias de simbolismo complexo, o que faz da história dos homens uma dimensão de realidade dependente de um ultra mundo, de uma realidade não-empírica, não fenomênica. Assim é que a perspectiva cosmológica de Vieira ainda se constitui num jogo de equivalências hierárquicas. Trata-se do recurso da alegoria, recurso por meio do qual "o acontecimento sensorial empalidece, sobrepujado pela significação figurada". ${ }^{14}$ Sem dúvida, a ideia da alegoria parece ser mesmo pertinente como elemento teórico de análise das imagens régias no pensamento histórico e político de Vieira. Isso porque, nos círculos eclesiásticos do século XVII, essa forma de

${ }^{14}$ Cf. AUERBACH, Eric (2002), Mimesis: a representação da realidade na literatura ocidental. São Paulo: Perspectiva, p. 41. 
representação ainda estava bem viva. Nos textos históricos e políticos escritos por Vieira parece ser possível identificar numerosas exemplificações desses esquemas alegóricos. Como disse um de seus mais autorizados biógrafos, "a sua capacidade de crer no maravilhoso era enorme, sem nisso se distinguir da média dos contemporâneos". 15

Em Vieira, uma razão superior orienta o sentido do mundo para o Quinto Império. Mas, antes mesmo da elaboração das concepções de Vieira, os textos de História apelavam para um destino glorioso de Portugal como uma espécie de exigência do plano divino do mundo. A celebração da façanha de Ourique é um desses grandes exemplos das coisas passadas, a reafirmar um destino grandioso para a nação. Segundo as crenças populares ao tempo de Vieira, Deus havia descido à terra, para fundar o novo Estado, e conversou pessoalmente com Afonso Henriques sobre este assunto. Contudo, há sutilezas que precisam ser observadas: se, por um lado, a existência terrena é um drama teleológico, cujo sentido já está definido antes de se completar, não deixa de requerer ações humanas bem dirigidas. É que a Providência cobra dos homens a sua parte. Assim, fazer o que compete a cada um em sua própria esfera de obrigações é um dever incontornável. Contudo, mais grave responsabilidade será imputada aos omissos:

"Sabei, cristãos, sabei, príncipe, sabei, ministros, que se vos há de pedir estreita conta do que fizestes, mas muito mais estreita do que deixastes de fazer. Pelo que fizeram, se hão de condenar muitos; pelo que não fizeram, todos. As culpas por que se condenam os reis são as que contêm nos relatórios das sentenças; lede agora o relatório da sentença do dia de Juízo, e notai o que diz: (...) Ide, malditos, ao fogo eterno. E por quê? (...) Cinco cargos e todos omissões: por que não destes de comer, por que não destes de beber, por que não recolhestes, por que não visitastes, por que não vestistes. Em suma, que os pecados que ultimamente hão de levar os condenados ao inferno são os pecados de omissão". 16

De uma passagem tão vigorosa, toma-se conhecimento que, segundo a concepção de Vieira, não há escapatória fora do movimento, e que a toda inatividade o preço cobrado é sempre o mais alto. Ao cristão não cabe vagar no deserto nem se meter em uma cova. Há que andar entre os homens, circular nas praças. Do contrário, perde-se a própria alma, e a dos outros, sugeria ainda no "Sermão da Primeira Dominga do Advento". Como escreve um estudioso do Barroco, "Os jesuítas difundem certas formas de vida religiosa nas quais, como é

\footnotetext{
15 AzEvedo, João L. (1984), A evolução do sebastianismo. Lisboa: Editorial Presença, p. 63.

${ }^{16}$ VIEIRA, António. «Sermão da Primeira Dominga do Advento». Op. cit., p. 78s.
} 
sabido, o papel da experiência, procedente do plano do sensível, tem importante destaque". ${ }^{17}$ Em Vieira, sagrado e profano entrelaçam-se.

Para Vieira, o conhecimento da história já vem constituído na veracidade dos fatos narrados por expressões de autoridade como Isaías, Daniel, etc. Em seus textos, Vieira por vezes utiliza-se da falácia da autoridade, como se, por exemplo, o latim de autores que desconheciam esta língua fosse a fonte cristalina de revelações da verdade. O latim qualifica a dignidade sacra do discurso teológico-político. Nessa língua se expressaram Santo Agostinho, São Jerônimo, São Tomás de Aquino, e mais uma casta celebérrima de doutores. Santo Agostinho e São Jerônimo, por exemplo, eram matrizes de argumentos de notável atualidade. Isso significa que existia uma unidade entre a filosofia que interpreta o passado e aquela que já o interpretou, num dado momento do passado. É como se a reflexão histórica de Vieira fosse coetânea daquela que é o seu fundamento, porque se assume dotada da mesma natureza, esperando alcançar os mesmos propósitos.

Teólogo polemista e moralista comprometido com a causa régia, a sua teologia política se esforça em captar, de um aglomerado complexo de fatos antigos, um sentido providencial, uma "linha" de desenvolvimento, para provar que Deus atua diretamente no mundo dos homens. Para Vieira, as conclusões da teologia são mais certas que as da filosofia natural:

"Assim que podemos dizer em uma palavra que a primeira e principal fonte e os primeiros e principais fundamentos de toda esta História é a Escritura Sagrada; com que vem a ser um só livro e um só Autor o que nela principalmente seguiremos: o livro, a Escritura; o Autor, Deus". ${ }^{18}$

Segundo Vieira, os príncipes que defendem o patrimônio de Cristo nada têm a temer. A história de suas ações é a história da realização plena de projetos do Filho do homem. Ainda que conheça percalços em sua trajetória, o príncipe cristão deve seguir confiante o seu caminho. A prova da interferência divina como escudo protetor de suas ações é buscada em exemplos heróicos do passado. São as ditas "façanhas estupendas", por meio das quais os reis cristãos triunfaram sobre os infiéis, mesmo quando inferiorizados pelo enxame das tropas inimigas. Assim é que os pequenos exércitos dos príncipes cristãos, bafejados por "enchentes de misericórdia", alcançaram vitórias exemplares. De todo modo, e apesar do concurso de Deus, o jesuíta apregoa que ao príncipe cristão cabe garantir-se pelas

${ }^{17}$ Maravall, José A. (1997), A cultura do Barroco. São Paulo: Edusp, p. 281.

${ }^{18}$ VIEIRA, Antônio. História do Futuro. Op. cit., p. 229 
armas. Isso porque as diferenças entre os príncipes seculares nem sempre se resolvem satisfatoriamente nas mesas de negociação.

Sob esse aspecto, Vieira não deixa margem a ambigüidades: ao príncipe cristão não cabem apenas rezas e meditações. Esse personagem deve empenhar-se na organização de um exército nacional, de preferência com milícia católica. Vieira sabia que a força das armas é o instrumento que faz ou desfaz reinos. Contra a "infecção doutrinal" imposta à cristandade por Lutero e Calvino, o receituário do Vieira conselheiro dos príncipes prescreve remédios um pouco amargos. A metáfora do cirurgião com o seu bisturi - que também se encontra em Maquiavel -, aparece com um sentido semelhante. Se uma parte do corpo político foi tomada pela gangrena da heresia, extirpe-se o membro corrompido e a questão se resolverá. É a sua "poção salvadora" para a ocupação holandesa do Brasil, da forma como aparece concebida em seu "papel forte". Como tudo em Vieira é metaforizável, a dita extirpação de um membro gangrenado simboliza a cessão de Pernambuco aos heréticos holandeses, mediante indenização a Portugal.

Abrindo espaço para uma rápida digressão, há indicativos traços de antimaquiavelismo em Vieira: a sua crítica à roda da fortuna é um exemplo. Está certo que se trata de uma crítica velada a Maquiavel. Mas seria possível ou mesmo pertinente descobrir certos ares de maquiavelismo nos textos de Vieira? Ao que parece, quando esta lógica mostra-se útil aos propósitos de sua razão de Estado, a resposta é positiva. De fato, há um "maquiavelismo celeste" e, para Vieira, a bondade das obras revela-se nos fins alcançados. Os instrumentos podem ser maus. "Não há fins sem meios", lembra Alcir Pécora em sua análise sobre a razão de Estado de Vieira. ${ }^{19} \mathrm{Em}$ se tratando das obras de Deus, não há distinção, já que todas são boas, ainda que alguns meios de que se sirva a Providência possam ser maus, ou parecer que o são. Essa é uma espécie de conversão do maquiavelismo político, agora transformado para servir aos propósitos da teologia política de Vieira. Embasando a sua consistente e, por vezes até agressiva teoria da ação, Vieira escreve no "Sermão de São Roque", acerca da propriedade de o eremita Elias receber o pão das unhas dos corvos:

"E a razão disto, qual é? A razão é porque a bondade das obras está nos fins, não está nos instrumentos. As obras de Deus todas são boas; os

${ }^{19}$ PÉCORA, Alcir (1999), «Política do céu — anti-Maquiavel». In: NovAES, Adauto. (Org.). Ética. São Paulo: Companhia das Letras. 
instrumentos de que se serve, podem ser bons e maus". ${ }^{20}$

Vieira revela em seus textos de eloqüência sagrada uma sensibilidade aflorada para enxergar o que quer que possa adaptar às suas concepções teológicas. Como mestre das metáforas mais complexas, que vai descarregando em jatos de imaginação, a tudo transforma em imagens eloqüentes, em um variado e colorido desfile de hipérboles. São as facetas do "pensar simbólico" característico do Seiscentismo ibérico, na interpretação de António Sérgio. Vieira compara as ordens sociais aos elementos da natureza, a propósito de questões tributárias, propondo uma distribuição mais equânime entre clero, nobreza e arraia miúda.

Um elemento que revela traços de modernidade em seu pensamento social está no combate que promoveu contra aquilo que, na França, implicava em derogéance: a perda do status social, status este limado pela participação da nobreza em atividades como o pequeno comércio ou a produção industrial. Portugal à época de Vieira era uma organização social que inutilizava para a riqueza geral os bens conventuais (bens de mão-morta) e para o trabalho produtivo os filhos segundos, feitos frades ou condenados à domesticidade aqueles não coubessem nos quadros da magistratura ou do exército haja vista que o trabalho mecânico — fossem atividades industriais, agrícolas ou mercantis —, era considerava aviltante". Na contramão desse tipo de ethos nobiliárquico, Vieira propõe desengastalhar os propulsores da prosperidade e opulência do Estado, por meio da notabilização dos comerciantes, os de "grosso trato e os de vara e côvado", ou seja, os grandes e os pequenos.

Em seus conselhos ao príncipe era notória a sua capacidade em traduzir os termos de complexidade de um processo e exprimi-los em alguns pontos bem claros e específicos. Entre opções variadas e por vezes arriscadas no xadrez político europeu, Vieira sabia revelar as questões cruciais em jogo. Aqueles que o criticaram, muitas vezes o fizeram por seus excessos de imaginação. Para seus adversários ele seria a "sereia do Palácio", o responsável pelos maiores naufrágios políticos de Portugal. Na avaliação de seus críticos contemporâneos, Vieira tornouse um estrategista tão atrapalhado ao ponto de os inimigos do reino zelarem melhor pelos interesses de Portugal. O exemplo mais recorrente era a proposta da nova união ibérica, que fora recusada pelo rei espanhol. Para seus detratores, ele queria entregar o ouro, e ainda premiar os bandidos por aceitá-lo. O seu prestígio junto a D. João IV ligava-se — nos cerca dos quinze anos gloriosos que passou sob a tutela

20 VIEIRA, António (2002), «Sermão de São Roque». In: PÉCORA, Alcir. (Org.). Escritos Históricos e Políticos. Pe. Antônio Vieira. São Paulo: Martins Fontes, p. 58. Esse sermão foi proferido em Lisboa, na Capela Real, no ano de 1644. 
protetora do rei —, à realeza de seu espírito. $\mathrm{O}$ brilho de sua inteligência atendia plenamente às exigências do espírito de realeza do soberano e, depois, da regente Dona Luísa.

Os dons intelectuais de Vieira, notadamente na arte da retórica sagrada, franquearam-lhe acesso privilegiado às altas instâncias do poder político, na esfera civil e eclesiástica. Nos anos 1640, entrava e saía do paço com a desenvoltura de um príncipe de sangue. Junto ao papa, anos depois, conseguiu escudo protetor contra os inquisidores. O rei torna-o o seu pregador, nomeia-o para missões diplomáticas pela Europa, eleva-o a embaixador na Holanda. Os arcanos da alta política passam a ser a atmosfera natural do padre Vieira. No tempo de D. João IV não havia matéria que lhe fosse estranha. Controvérsias sobre crenças religiosas, alianças matrimoniais e dinásticas, problemas de ordem eminentemente econômica - como assuntos fiscais e de comércio - e muito mais ainda, tudo era apresentado a Vieira, que emitia pareceres em forma de cartas e opúsculos. Gozando da amizade e confiança do rei, e depois da simpatia da regente, a autoridade que lhe era reconhecida em praticamente todas as matérias foi notória por mais de vinte anos.

Margarida Vieira Mendes percebe nos textos de Vieira uma oratória sagrada cheia de aspectos profanos. $^{21}$ Se a política cristã é sempre o fio condutor do discurso de Vieira, nela se misturam, por exemplo, temas tão seculares como as companhias de comércio e a complexa questão judaica. Diga-se de passagem, ao pregador régio o caminho estava livre, para converter acontecimentos da história vivida em discurso religioso, para mostrar o dedo de Deus sobre os sucessos passados, presentes e por vir. Assim, revelava aos homens as verdades encobertas, verdades que estavam somente ao alcance do pregador inspirado pelos textos sagrados.

Nessas dimensões mundanas da política cristã de Vieira há que se destacar o seu realismo político, sempre em acordo com as complexas circunstâncias impostas pela realidade econômica de Portugal nos meados do século XVII. Daí decorrem, colados às coordenadas morais para a edificação da consciência do príncipe, os aspectos pragmáticos das mensagens de Vieira. Há, como já observado, espaço para certo maquiavelismo, que endossa o emprego de instrumentos imperfeitos para a realização da política cristã. Assim sendo, os tais instrumentos imperfeitos seriam recursos válidos, desde que produzissem bons resultados.

${ }^{21}$ Cf. Mendes, Margarida V. (1989), A oratória barroca de Vieira. Lisboa: Editorial Caminho. 
Utilizando-se de pressupostos da exegese pós-estruturalista francesa para a interpretação dos textos de Vieira, Margarida Vieira Mendes observa que os argumentos do autor são ações verbais utilizadas para uma ocasião específica, para determinados contextos que requeriam uma mensagem de intervenção. $\mathrm{O}$ sermão era a trombeta que alertava para os perigos que corria a monarquia. Mas, mesmo sendo obra de circunstância, o sermão podia adquirir diferentes sentidos, passando a valer para mais de uma ocasião. Quando proferido do púlpito, seu destino preferencial era o príncipe reinante. Quando, tempos depois, o discurso destinavase à publicação, o texto podia sofrer alterações e adaptações, para servir a novas circunstâncias, com o fito de alcançar, com maior eficácia, a consciência moral de um novo príncipe.

De fato, muitos sermões de Vieira ficaram no estado de rascunhos. Foram refeitos com a inserção de novos acontecimentos. O resultado final era um texto atualizado que incorporava as experiências ulteriores do autor. Era dessa forma que o discurso político de Vieira se renovava, para fazer frente às alterações no palco das decisões. Quase todos os escritos de Vieira são obras marcadas por um contexto específico, que lhe exigia uma intervenção em forma de crítica, de exortação, ou mesmo de elogio.

Contudo, a entrada em cena de novos personagens nas esferas mais elevadas do poder reduziu progressivamente a eficácia dos sermões de Vieira. Ao deparar-se com audições altamente seletivas, como as de D. Afonso VI e de D. Pedro II, Vieira insistiu na necessidade de que os grandes deste mundo não deixassem de ouvir conselhos. Para Vieira, em sermão de 1639, nem mesmo o mais célebre dos príncipes conquistadores, Alexandre Magno, desmerecia conselhos:

"Para conseguir effeitos grandes, e para levar ao cabo emprezas difficultosas, mais segura é uma ignorancia bem aconselhada, que uma sciencia presumida. (...) Perguntado Alexandre Magno com que industria, ou com que meios em tão breve tempo se fizera senhor do mundo, diz Estrobeo, que respondêra estas palavras: Consiliis, eloquentia, et arte imperatória: Com os conselhos, com a eloqüência, e com a arte de governar exércitos. No ultimo lugar poz a arte, e no primeiro o conselho; porque o conselho é a arte das artes, e a alma e intelligencia do que ella ensina". 22

É o conselho que permite refletir e reconhecer as inúmeras particularidades de uma ação, os seus riscos específicos, bem como as vantagens e desvantagens do

22 VIeIRA, Antonio. «Sermão da Santa Cruz». In: CAlmon, Pedro. (Org.) (1933), Sermões Patrióticos. In: Calmon, P. (Org.). Sermões Patrióticos. Rio de Janeiro: Edições Biblos, pp. 61s. 
terreno e das circunstâncias. Assim sendo, os reis devem pedir conselho. O próprio Cristo o fez. Então, Vieira se sentia autorizado a distribuí-los. Nesse terreno, a sua matéria-prima eram os exemplos bíblicos e as alegorias dos profetas.

É certo que a liberdade de púlpito facultava-lhe a abordagem de temas delicados. No púlpito, escudo protetor contra os adversários da corte e os de outras ordens religiosas, Vieira estava livre para despejar as suas ideias polêmicas. A eloqüência sagrada prestava-lhe um grande serviço: abria-lhe o caminho da crítica às coisas profanas. $\mathrm{E}$ a sua coragem para amplificar o verbo não derivava simplesmente da proteção régia. O pregador tinha consciência de que, em seu papel, também era filtro dos desígnios de Deus. Reiterando não ser profeta, atuava como se o fosse, porque a mais elevada das suas missões era a de desvendar os mistérios ocultos da história, sempre em favor da monarquia lusitana.

Decifrador dos mistérios escondidos nos textos sagrados, ele pretendeu ditar as normas para a boa navegação da nau do Estado. Para tanto, soube extrair das Sagradas Escrituras tudo o que era necessário para debater as questões mais relevantes do tempo presente. Homem de ação, nas mãos de Vieira, a pena foi convertida em sabre, ou seja, em instrumento de intervenção. Utilizando-se da eloqüência sagrada ele desejou estabelecer a verdadeira política cristã, por intermédio da instrução do soberano. Do púlpito, não se preocupava tanto em utilizar seus dotes de orador para impressionar a seu público. Pragmático, voltado para a realização das ações que pretendia desencadear com seus discursos, voltavase para ativar o sentimento de quem possuía o poder de intervir.

De fato, muitos trechos dos sermões desenvolvem uma técnica da administração, ou melhor, uma arte de reinar. Nos sermões, há uma ciência da política em fragmentos, para servir de orientação aos príncipes. Delineando o seu príncipe-modelo, traçando as diretrizes da monarquia, Vieira estava em seu ambiente natural, haja vista ser de sua competência, na qualidade de pregador régio, os conselhos morais ao príncipe. Como afirma Margarida Vieira Mendes, o sermão é, normalmente, uma "Arte do Príncipe", obra concebida e narrada pelo consultor e guia do monarca, que com ele priva de amizade e confiança. Sob esse aspecto, Vieira extrapolou as funções de diretor da consciência régia.

Ora, ele não se limitou a traçar o plano das ações necessárias a um soberano cercado por poderosos adversários. Quis revelar o futuro de um reino. Assim, foi muito além dos tradicionais conselheiros de cabeças coroadas. Ao que parece, os sermões proferidos em Lisboa, nos anos 1640, são os mais propícios à análise das virtudes principescas e da ideia do bom governo. De fato, foi nos primeiros anos da Restauração que Vieira desfrutou de maior prestígio e poder de influência na 
política lusitana. Nesses anos, ele tornou-se pregador de D. João IV e preceptor do infante, D. Teodósio. Muitos dos sermões dessa década têm a realeza como tema. É quando Vieira demonstra todo o seu talento para farejar um tema profano e enquadrá-lo numa moldura religiosa.

Como já afirmado, Vieira não se considerava profeta, ao menos segundo o padrão fixado pela tradição bíblica. Tinha-se na condição de um pregador da palavra a serviço da monarquia. A sua maior ambição intelectual foi a de ser intérprete dos textos proféticos da Bíblia. De fato, há muitos trechos em que Vieira se empenhou em acentuar a sua inaptidão para ser oráculo do futuro, aquele que enxerga diretamente os sucessos que estão por vir. Negando a si o dom da profecia e afirmando ser apenas intérprete das verdades encobertas nas Escrituras Sagradas, ainda assim Vieira se viu em maus lençóis nos finais dos anos 1660. Segundo Margarida Vieira Mendes, os inquisidores de Coimbra o qualificaram como "profeta marginal" apanhado em contradição com a dogmática em vigor.

Em síntese, o papel de Vieira, e que ele desempenhou com gana e talento, foi o de conselheiro do príncipe, o "braço armado" de um arsenal de ideias úteis para guiar a nau do Estado ao porto seguro da concórdia. Então, seria pertinente ler a obra de Vieira como um gênero espelho de príncipes, ao menos naquelas dimensões residuais que permanecem em várias obras do século XVII e que esboçam lições políticas e traçam uma imagem idealizada do soberano? Respondendo afirmativamente, acredita-se existir em seus textos históricos e políticos uma especial vitalidade dessa dimensão "espelho do príncipe" como, por exemplo, nas cartas aos reis, rainhas e à nobreza, bem como em alguns de seus sermões e na História do Futuro. O esforço de legitimação de D. João IV à época da Restauração acentua esse interesse de Vieira por questões relativas à soberania do novo príncipe. Daí a recorrência, mormente nos escritos dos anos 1640, de temas como os pressupostos teológico-políticos da monarquia e a exemplaridade das ações principescas.

Com efeito, fazer do príncipe um governante virtuoso com o fito de que ele reinasse bem persistiu como um traço significativo da obra de reflexão moral para muito além da ideia medieval do bom governo. A título de ilustração, lições aos príncipes é o que não falta no "Sermão histórico e panegírico, nos anos da Sereníssima Rainha Nossa Senhora", texto no qual o autor concebe a imagem do príncipe cristão modelar na pessoa do falecido D. João IV, o rei que the prodigalizou todas as mercês: "Que retrate naquele espelho as reais ações, que 
imite naquele exemplar as virtudes heróicas, que estude naquele livro aberto as lições que só a sabedoria do divino Espírito lhe pode ensinar ...". 23

Apesar do conteúdo arrojado de suas abordagens sobre as formas de ação de uma monarquia moderna, há uma esfera de atuação política que é apanágio do príncipe virtuoso. É nesse espaço que se pretende "forçar" Vieira em outras abordagens de seus textos, contrastando os elementos quinhentistas de sua formação teológico-religiosa com a visão atualizada da realidade de seu mundo. Ele sabia que o Duque de Bragança era um príncipe novo, cuja fonte de poder ainda não era inquestionável e que, bem ao contrário, era contestada e disputada por uma poderosa força externa. Com efeito, a Restauração, ao tempo de Vieira, não fora reconhecida nem pela Espanha nem pelo papado, e só o seria muito tempo depois.

Assim é que as admoestações de Vieira ao rei da Espanha - o inimigo a quem é preciso oferecer a resistência das armas e também das ideias —-, assumem aspectos flamejantes em sua História do Futuro. O braço armado da Providência castiga os súditos infiéis ao rei de Portugal nas lutas com a Espanha, após a Restauração. A morte e o desterro serão pagas justas aos traidores do príncipe. Vencer Portugal é impossível. Trata-se do exército do Senhor. Que apoio providencial a um príncipe em busca de reconhecimento poder dispor de uma mente fértil e brilhante como a desse devotado colaborador!

A usina criativa de ideias do jesuíta cortesão abastecia o príncipe com os recursos necessários para a luta em prol das alianças no intrincado cenário político europeu, num tempo em que tratados feitos para durar ofereciam, na prática, uma fraca resistência às conveniências circunstanciais das cabeças coroadas. Em meio a esses complexos jogos de interesses, sendo necessário oferecer respostas eficazes em curto prazo às urgências da monarquia lusitana, Vieira segue como enviado especial à Holanda, para atuar como "olheiro" do rei em tempo integral. Essa condição de agente do príncipe colocou-o, por vezes, em situações de interventor em polêmicas espinhosas. Exemplo: o texto intitulado "Proposta feita a El-Rei D. João IV em que lhe representa o miserável estado do Reino e a necessidade que tinha de admitir os judeus mercadores que andavam por diversas partes da Europa". Ora, judeus e cristãos-novos eram agentes econômicos muito mais dinâmicos e empreendedores do que os chamados cristãos de sangue limpo, ou cristãos-velhos. Vieira compreendeu que era urgente a necessidade de reintegrar

23 VIEIRA, António. «Sermão histórico e panegírico, nos anos da Sereníssima Rainha Nossa Senhora». Op. cit., p. 181. 
essa gente poderosa às forças produtivas do reino, pela via do trabalho, da economia, sem fazer uso de expedientes de apropriação extra-econômicos. Mas o fanatismo religioso imperante entre as poderosas ordens religiosas entendia que só a violência sagrada dos meios inquisitoriais justificava a apropriação do dinheiro sujo dos judeus. Assim, o seu ouro podia ser lavado da nódoa da infame origem.

A sua atividade intelectual foi autêntico trabalho de engajamento político, a ponto de se afirmar, acertadamente, que todo texto de Vieira traz uma mensagem política. Com efeito, do gabinete ou do púlpito, ele sempre lançava palavras de ordem que traziam um conteúdo programático para a ação. Não são apenas diagnósticos de situações específicas ou conteúdos puramente descritivos de certas realidades o que se pode apurar no discurso político de Vieira. O nível de intenção predominante em sua elaboração intelectual, no plano de uma reflexão política, é quase sempre prescritivo: as suas reflexões são propostas concretas, uma espécie de manual prático para as ações necessárias, mesmo que seguindo as normas com que se apresentavam as lições aos poderosos no século XVII. Os conselhos à coroa requeriam uma linguagem e um arranjo segundo certas habilidades retóricas de quem os oferecia. Assim, cabia ao conselheiro do príncipe dar as suas lições com um tom e um vocabulário que não forçassem muito os limites dos valores reconhecidos, ainda que por vezes ele tenha transgredido tais limites.

O conselheiro se esforçava em delicadas manobras de persuasão. Em sermão pronunciado no dia de ano novo - em 1642, diante do rei e da nobreza afirmou ser D. João IV o redentor prometido. Anos mais tarde, no sermão das exéquias desse "invicto rei", de 1657, compara-o ao grande rei Davi. Como Davi, que fora indicado rei após um desfile de vários pretendentes — Eliabe, Abinadabe, Sama - também o duque de Bragança foi escolhido diretamente por Deus para reinar em Portugal, dentre um seletíssimo grupo de "príncipes pretensores à coroa". A “arte de furtar" das Sagradas Escrituras — e de outras fontes também — o que lhe é conveniente às suas homenagens obrigadas é um exercício levado a cabo com a desenvoltura de quem apanha um recurso para promover um bem maior. É quando entra em cena o esgrimista Vieira, descarregando seus golpes sobre os adversários que vai encontrando pelo caminho. A partir das dimensões preceptivas encontradas de forma tão recorrente em vários de seus textos, talvez não se constitua uma hipótese exagerada afirmar que Vieira tenha se percebido como um guia realmente qualificado para instruir as ações dos governantes. Se as suas toadas foram mesmo um canto enganador e perigoso, mormente quando destinadas a desencadear ações políticas, é algo já foi objeto das considerações dos homens de seu tempo. A nós cabe especular que o tema possui alto relevo em seu rico universo temático e que talvez mereça uma reflexão mais disciplinada e mais extensa. 


\section{BIBLIOGRAFÍA}

AuERBACH, Eric. Mimesis: a representação da realidade na literatura ocidental. São Paulo: Perspectiva, 2002.

AzEVEDO, João L. A evolução do sebastianismo. Lisboa: Editorial Presença, 1984.

AzEVedo, João L. História de António Vieira. Lisboa: Livraria Clássica, 1931. Vol. 2.

Maravall, José A. A cultura do Barroco. São Paulo: Edusp, 1997.

MENDES, Margarida V. A oratória barroca de Vieira. Lisboa: Editorial Caminho, 1989.

PÉCORA, Alcir. «Política do céu — anti-Maquiavel». In: NovAES, Adauto. (Org.). Ética. São Paulo: Companhia das Letras, 1999.

PÉCORA, Alcir. Teatro do Sacramento: a unidade teológico-retórico-política dos sermões de Antônio Vieira. São Paulo: Edusp, 1994.

SÉrgIO, António. «Prefácio». In: VIEIRA, António. Obras escolhidas do padre Antonio Vieira. Carta I, Volume I. Porto: Lello \& Irmão, 1951.

VIEIRA, António. «Sermão da Primeira Dominga do Advento». In: PÉCORA, Alcir. (Org.). Escritos Históricos e Políticos. São Paulo: Martins Fontes, 2002.

VIEIRA, Antonio. «Sermão da Santa Cruz». In: CALmon, Pedro. (Org.). Sermões Patrióticos. In: Calmon, P. (Org.). Sermões Patrióticos. Rio de Janeiro: Edições Biblos, 1933.

VIEIRA, António. «Sermão de ação de graças pelo nascimento do príncipe D. João». «Sermão de ação de graças pelo nascimento do príncipe D. João, primogênito de SS. Magestades, que Deus guarde (1688)». In: —. Obras completas do padre Antonio Vieira. Porto: Lello \& Irmão, 1951. Volume XV.

VIEIRA, António. «Sermão de São Roque». «Sermão de São Roque». In: PÉCORA, Alcir. (Org.). Escritos Históricos e Políticos. Pe. Antônio Vieira. São Paulo: Martins Fontes, 2002.

VIEIRA, António. «Sermão histórico e panegírico, nos anos da Sereníssima Rainha Nossa Senhora». In: —. Sermões. São Paulo: Editora das Américas, 1957. Volume XXII.

VIEIRA, António. História do Futuro. Brasília: Editora da UnB, 2005. (Organização: Aleixo, José C.B.). 